Justyna Ożegalska-Trybalska ${ }^{1}$

\title{
MODEL NABYCIA I KOMERCJALIZACJI PRAW DO WYNIKÓW BADAŃ NAUKOWYCH I PRAC ROZWOJOWYCH W ŚWIETLE USTAWY - PRAWO O SZKOLNICTWIE WYŻSZYM
}

\section{Uwagi ogólne}

Od wielu lat problematyka zarządzania własnością intelektualną jest wpisana w misję uczelni i stanowi jedno z nowych wyzwań, przed jakimi stoją jej władze oraz tworzący dobra niematerialne pracownicy, studenci i doktoranci. ${ }^{2}$ Ten aspekt zarządzania uczelnią obejmuje różnego rodzaju działania w zakresie zabezpieczenia ochrony i komercjalizacji dóbr niematerialnych powstających w ramach procesów badawczych i dydaktycznych, jak również politykę poszanowania cudzej twórczości i przeciwdziałania naruszeniom praw autorskich.

W tym zakresie, swoboda kształtowania przez uczelnie zasad zarządzania wytworami intelektualnymi jest ograniczona ustawowymi zasadami przewidzianymi w ustawie - Prawo o szkolnictwie wyższym z 2005 r. ${ }^{3}$ (dalej p.s.w.), rozbudowanymi i zmodyfikowanymi nowelizacjami z: $2011 \mathrm{r}^{4}$ oraz $2014 \mathrm{r}^{5}$

Ostatnia nowelizacja (która weszła w życie w dniu 1 października 2014 r.) wniosła do modelu zarządzania własnością intelektualną na uczelniach publicznych wiele istotnych zmian. W szczególności, wprowadziła nowy tryb wykonywania i komercjalizacji przez uczelnię publiczną ${ }^{6}$ praw do wyników badań naukowych i prac

1 Doktor nauk prawnych, Katedra Prawa Własności Intelektualnej Wydziału Prawa i Administracji Uniwersytetu Jagiellońskiego.

2 Szerzej: D. Kasprzycki, J. Ożegalska-Trybalska, Prawne aspekty zarządzania własnością intelektualną na uczelniach. Zagadnienia wybrane, (w:) A. Matlak, S. Stanisławska-Kloc (red.), Spory o własność intelektualną, Księga jubileuszowa dedykowana Profesorom Januszowi Barcie i Ryszardowi Markiewiczowi, Warszawa 2013, s. 399-427.

3 Tekst jedn. Dz.U. z 2012 r. poz. 572.

4 Dz.U. Nr 84, poz. 455.

$5 \quad$ Dz.U. z 2014 r. poz. 1198.

$6 \quad$ Niektóre ze znowelizowanych przepisów odnoszą się do uczelni niepublicznych. Na mocy przepisów przejściowych ustawy nowelizującej zostały zmienione: art. 94 ustawy z dnia 30 kwietnia 2010 r. o Polskiej Akademii Nauk (Dz.U. z 2010 r. Nr 96, poz. 619 z późn. zm.) oraz art. 17 ustawy z dnia 30 kwietnia 2010 r. o instytutach badawczych (Dz.U. z 2010 r. Nr 96, poz. 618 z późn. zm.). 
rozwojowych tworzonych przez pracowników, uzupełniając w tym zakresie przepisy dotyczące twórczości pracowniczej, przewidziane $\mathrm{w}$ ustawie o prawie autorskim i prawach pokrewnych z 4 lutego 1994 r. (dalej ,pr.aut.”) $)^{7}$ oraz ustawie Prawo własności przemysłowej z 30 czerwca 2000 r. ${ }^{8}$ (dalej ,p.w.p.”).

Niniejszy artykuł ma na celu omówienie najważniejszych rozwiązań dotyczących tej problematyki przewidzianych w p.s.w. $z$ jednoczesnym zasygnalizowaniem tych kwestii, które mogą w zakresie stosowania tych przepisów rodzić problemy interpretacyjne.

\section{Struktura organizacyjna oraz narzędzia prawne wspierające procesy zarządzania własnością intelektualną uczelni}

Jednym z warunków prowadzenia efektywnych procesów identyfikacji, ochrony i komercjalizacji własności intelektualnej tworzonej na uczelniach jest dostosowanie struktury organizacyjno-prawnej uczelni do realizacji zadań w zakresie zarządzania własnością intelektualną. Ostatnia nowelizacja wprowadziła w tym zakresie stosunkowo niewielkie zmiany pozostawiając centra transferu technologii (dalej „CTT”) oraz uczelniane spółki celowe jako podmioty dedykowane do wspierania takich procesów. Doprecyzowane natomiast zostały zadania CTT i podział kompetencji między CTT i spółkę celową. ${ }^{9} \mathrm{~W}$ świetle znowelizowanych przepisów pierwsze są odpowiedzialne za komercjalizację bezpośrednią, ${ }^{10}$ natomiast działania w zakresie komercjalizacji pośredniej ${ }^{11}$ (lub komercjalizacji bezpośredniej w przypadku powierzenia spółce zarządzania własnością intelektualną) stanowić mają domenę działalności spółki celowej. ${ }^{12}$

O ile jednak wcześniej uczelnie miały możliwość wyboru formy prawnej dla CTT, obecnie może ono funkcjonować wyłącznie w formie jednostki ogólnouczelnianej, działającej na podstawie regulaminu zatwierdzonego przez odpowiednie organy uczelni. Z kolei, spółka celowa może być utworzona jedynie w formie jednoosobowej spółki kapitałowej (art. 86a p.s.w.), co oznacza, że w aktualnym stanie prawnym nie jest możliwe pełnienie przez CTT roli takiej spółki. W świetle aktu-

Tekst jedn. Dz.U. z 2006 r. Nr 90, poz. 631 z późn. zm.

Tekst jedn. Dz.U. z 2013 r. poz. 1410.

Szczegółowo na ten temat: K. Gurba, M. Czarnik, Zasady współpracy między spółką celową a centrum transferu technologii, centrum transferu technologii a uczelnianym inkubatorem przedsiębiorczości, (w:) J. Ożegalska-Trybalska (red.), Regulaminy zarządzania własnością intelektualną w szkołach wyższych w świetle znowelizowanej ustawy Prawo o szkolnictwie wyższym. Poradnik, Warszawa 2015, s. 78-79.

Zgodnie z art. 2 ust. 1 pkt 35 p.s.w. jest to „sprzedaż wyników badań naukowych, prac rozwojowych lub know-how związanego z tymi wynikami albo oddawanie do używania tych wyników lub know-how, w szczególności na podstawie umowy licencyjnej, najmu oraz dzierżawy".

Komercjalizacją pośrednią jest obejmowanie lub nabywanie udziałów lub akcji w spółkach w celu wdrożenia lub przygotowania do wdrożenia wyników badań naukowych, prac rozwojowych lub know-how związanego z tymi wynikami (art. 2 ust. 1 pkt 36 p.s.w.).

Zgodnie z art. 86b 1 p.s.w., spółka celowa może zostać utworzona przez kilka uczelni publicznych albo kilka uczelni niepublicznych. 
alnego brzmienia art. 86a p.s.w. nie ma wątpliwości, że ta forma organizacyjna ma charakter fakultatywny, tzn. uczelnie w zależności od swoich potrzeb mogą - ale nie muszą wyodrębniać ze swojej struktury odrębnego podmiotu w postaci spółki celowej.

Obok rozwiązań organizacyjnych, uczelnie dysponują prawnymi narzędziami służącymi do jednolitego stosowania ustawowych zasad dotyczących zarządzania własnością intelektualną wewnątrz uczelni w postaci regulaminów zarządzania prawami autorskimi i prawami własności przemysłowej oraz komercjalizacji, jak również - zgodnie z nowym brzmieniem at. 86c ust. 2 p.s.w. - regulaminów korzystania $z$ infrastruktury badawczej. Ustawa wprowadza nie tylko obowiązek uchwalenia takich regulaminów przez senat uczelni publicznej (a w przypadku uczelni niepublicznej organ wskazany w statucie), ale w art. 86c p.s.w. precyzuje ich obligatoryjny zakres. W odniesieniu do uczelni publicznych został on rozszerzony o zasady i obowiązki związane z nowym trybem komercjalizacji wyników badań i prac rozwojowych oraz podziałem środków z komercjalizacji, jak również o nowe obowiązki pracowników i studentów. ${ }^{13}$

W kontekście - z jednej strony - ustawowego źródła zasad nabycia praw własności intelektualnej przewidzianych w przepisach ogólnych (pr.aut., p.w.p.) oraz ustawowych zasad komercjalizacji praw do wyników badań i prac rozwojowych (p.s.w.), z drugiej zaś strony - obowiązku implementowania tych ostatnich do wewnętrznych regulaminów, pojawia się praktyczna kwestia dotycząca związania pracowników uczelni oraz innych kategorii twórców postanowieniami regulaminów. Chodzi tu w szczególności o pytanie, czy taki regulamin powinien być indywidualnie zaakceptowany przez każdego pracownika uczelni publicznej, czy też każdy pracownik jest ,automatycznie” związany jego postanowieniami, zwłaszcza tymi, z których wynikają uregulowane ustawowo prawa i obowiązki. Analogiczne pytanie dotyczy związania postanowieniami regulaminu studentów i doktorantów.

Trudność z jednoznaczną odpowiedzią na to pytanie polega na tym, że konkretny regulamin może zawierać postanowienia o zróżnicowanym charakterze, których skuteczność powinna być oceniana w sposób odmienny.

Jeżeli regulamin powtarza ustawowe przepisy o charakterze bezwzględnie obowiązującym można argumentować, że niezależnie od tego, czy są one zaakceptowane przez pracownika jako postanowienia regulaminu czy też nie, są one wiążące zarówno dla pracownika, jak i uczelni.

13 Zakres tych obowiązkowych elementów regulaminu precyzje art. 86 ust. 2 p.s.w., zgodnie z którym w regulaminie powinny zostać uregulowane: 1) zasady podziału środków uzyskanych z komercjalizacji między twórcą będącym pracownikiem uczelni publicznej a tą uczelnią; 2) zasady i tryb przekazywania uczelni publicznej przez pracownika, studenta lub doktoranta tej uczelni informacji o wynikach badań naukowych lub prac rozwojowych oraz o know-how związanym z tymi wynikami, informacji o uzyskanych przez pracownika środkach z komercjalizacji oraz zasady i tryb przekazywania przez pracownika przysługujących uczelni publicznej części środków uzyskanych z komercjalizacji; 3) zasady i tryb przekazywania pracownikowi przez uczelnię publiczną informacji o decyzjach o komercjalizacji lub niekomercjalizacji oraz zasady i tryb przekazywania przez uczelnię publiczną przysługujących pracownikowi części środków uzyskanych z komercjalizacji. 
Niezależnie od powyższego, jako podstawę związania zarówno pracowników, jak i studentów i doktorantów pozaustawowymi zasadami regulaminowymi - niezależnie od ich akceptacji - można wskazywać art. 65 p.s.w. Zgodnie z tym przepisem, wewnętrzny regulamin wydany $\mathrm{w}$ formie uchwały podjętej w zakresie kompetencji stanowiących przez senat uczelni publicznej - jest wiążący dla jej pracowników, studentów i doktorantów. ${ }^{14}$ Jak się wydaje, sama uchwała senatu nie może być jednak źródłem modyfikacji tych zasad ustawowych, które choć przewidują taką możliwość, narzucają obligatoryjną formę, w jakiej modyfikacja taka może być dokonana. Dotyczy to w szczególności przepisów art. 12 i 14 pr. aut. oraz art. 11 ust. 3 p.w.p., z których wynika, że możliwość odmiennego niż przewidziane w ustawie uregulowania kwestii nabycia praw może nastąpić w oparciu o umowę o pracę, co przemawia za przyjęciem rozwiązania polegającego na inkorporowaniu regulaminu uczelnianego lub przynajmniej niektórych jego postanowień do umów o pracę.

Także inne kategorie twórców, w tym studenci i doktoranci powinni znać i zaakceptować treść regulaminu po to, aby mógł on być przez nich respektowany, przy czym sama akceptacja regulaminu nie jest wystarczająca dla skutecznego związania postanowieniami, które modyfikują przepisy ustaw ogólnych określające zasady nabycia praw własności intelektualnej przez tę kategorię twórców. ${ }^{15}$

\section{Tryb nabycia i komercjalizacji praw do wyników badań naukowych i prac rozwojowych oraz know-how związanego z tymi wynikami}

Najważniejszym aspektem nowelizacji p.s.w. z 2014 r. w zakresie zarządzania własnością na uczelniach jest ustawowe uregulowanie trybu nabycia i komercjalizacji praw do wyników badań naukowych, prac rozwojowych oraz know-how związanego z tymi wynikami, uzyskanych przez pracownika $\mathrm{w}$ ramach wykonywania obowiązków wynikających ze stosunku pracy. Nowe zasady określa art. 86d p.s.w., który znajduje zastosowanie wyłącznie do twórców będących pracownikami uczelni publicznej (ograniczenie podmiotowe) oraz wyłącznie do tych przedmiotów ochrony prawami własności przemysłowej, które stanowią wyniki „badań naukowych i prac rozwojowych oraz know-how związanego z tymi wynikami” (ograniczenie przedmiotowe). Choć jak się wydaje założeniem ustawodawcy było ograniczenie zastosowania nowego trybu do mających potencjał komercjalizacyjny przedmiotów praw własności przemysłowej objętych ustawową definicją ,wyników badań naukowych” (wynalazków, wzorów użytkowych, wzorów przemysłowym, topografii układu scalonego, wyhodowanych lub odkrytych i wyprowadzonych odmian roślin), w świetle

14 Przepis ten stosuje się odpowiednio do uczelni niepublicznych.

15 Zob: J. Chlebny, Prawa i obowiązki uczelni, pracowników, studentów oraz doktorantów w zakresie ochrony i korzystania z praw własności intelektualnej, (w:) J. Ożegalska-Trybalska (red.), Regulaminy..., op. cit, s. 31-32. 
literalnej definicji ,prac rozwojowych”16 nie można wykluczyć ex lege możliwości zastosowania go także do przedmiotów praw autorskich, o ile w konkretnym przypadku będą one stanowić wynik takich prac. ${ }^{17}$

Należy zaznaczyć, że dalsze ograniczenia przedmiotowe stosowania ustawowego trybu nabycia i komercjalizacji wyników badań i prac rozwojowych wynikają z art. 86e ust. 4 p.s.w. Zawiera on wyłączenia w odniesieniu do wyników stanowiących rezultat badań lub prac zleconych i finansowanych (współfinansowanych) na podstawie umowy przewidującej zobowiązanie do przeniesienia praw do wyników badań naukowych lub prac rozwojowych na rzecz tej strony lub na rzecz innego podmiotu niż strona umowy, jak również prac z wykorzystaniem środków finansowych, których zasady przyznawania lub wykorzystywania określają odmienny niż w ustawie sposób dysponowania takimi wynikami. ${ }^{18}$

Istotą modelu przewidzianego w p.s.w. jest wprowadzenie ustawowego, 3-miesięcznego terminu, w którym uczelnia - po uzyskaniu od pracownika informacji o wynikach badań lub prac rozwojowych - powinna podjąć decyzję o komercjalizacji lub niekomercjalizacji. W razie podjęcia decyzji o braku zainteresowania komercjalizacją lub po bezskutecznym upływie tego terminu jest ona zobowiązana do złożenia pracownikowi oferty zawarcia bezwarunkowej umowy, ${ }^{19}$ a w przypadku jej przyjęcia - przeniesienia na niego tych praw za ustawowo określoną kwotę w wysokości nieprzekraczającej 10\% minimalnego wynagrodzenia za pracę, obowiązującego w dniu zawarcia umowy.

Należy podkreślić, że przewidziane w art. 86d p.s.w. rozwiązanie nie modyfikuje ogólnych zasad nabycia praw wynikających z przepisów pr. aut. czy p.w.p., a jedynie wprowadza ustawowe, czasowe ograniczenie praw uczelni jako pracodawcy w stosunku do pewnej kategorii wytworów intelektualnych tworzonych na uczelniach, tj. wyników badań naukowych i prac rozwojowych oraz know-how związanego z tymi wynikami uzyskanych przez pracownika w ramach wykonywania obowiązków wynikających ze stosunku pracy. ${ }^{20}$ Podjęcie przez uczelnię pu-

16 Wobec braku odmiennej definicji, w tym zakresie należy posłużyć się definicją prac rozwojowych zawartą w art. 1 ust. 3 ustawy z dnia 30 kwietnia 2010 r. o zasadach finansowania nauki (Dz.U. Nr 96, poz. 615 z późn. zm.), zgodnie z którą pracami rozwojowymi jest „nabywanie, łączenie, kształtowanie i wykorzystywanie dostępnej aktualnie wiedzy i umiejętności z dziedziny nauki, technologii i działalności gospodarczej oraz innej wiedzy i umiejętności do planowania produkcji oraz tworzenia i projektowania nowych, zmienionych lub ulepszonych produktów, procesów i usług".

17 Inaczej M. Salomonowicz, który przyjmuje, że art. 86 d p.s.w. nie wskazuje na utwory i prawa majątkowe - zob: Prawa do wyników badań, ich komercjalizacja oraz tzw. uwłaszczenie naukowców w prawie o szkolnictwie wyższym, „Monitor Prawniczy” 2014, nr 22, s. 1175.

18 Dotyczyć to będzie w szczególności projektów finansowanych przez Narodowe Centrum Badań i Rozwoju, Narodowe Centrum Nauki.

19 Choć w przepisach brak jest wskazówek co do rozumienia określenia „umowa bezwarunkowa”, należy przyjąć, że chodzi tutaj o taką umowę, która nie nakłada na pracownika warunków w rozumieniu art. 86 k.c. i/lub obowiązków, które z jednej strony mogłyby w praktyce „sparaliżować” wykonanie takiej umowy i skuteczne nabycie praw do wyników przez pracownika, $z$ drugiej zaś strony z uwagi na zobowiązania nałożone na niego umową mogłyby go zniechęcić do jej podpisania.

20 W sposób istotny różni się on od modelu pierwotnie zaproponowanego w rządowym projekcie ustawy nowelizującej (druk sejmowy 2085 z dnia 17 lipca 2014 r.), który zakładał przyznanie twórcom tworzącym na uczelniach 
bliczną decyzji o komercjalizacji w trybie 86d p.s.w. ma ten skutek, że nieskuteczne stają się ewentualne roszczenia pracownika o przeniesienie na niego praw do wyników badań przez uczelnię, która pozostaje w takiej sytuacji pierwotnie uprawniona z tytułu praw własności intelektualnej do wyników badań i prac rozwojowych. Decyzja uczelni ma zatem kluczowe znaczenie dla „potwierdzenia” praw do twórczości pracowniczej oraz pełnej swobody uczelni w zakresie dokonywania czynności prawnych obejmujących prawa do wyników badań. ${ }^{21}$ Nie można natomiast przypisywać decyzji o komercjalizacji charakteru prawno-kształującego w tym sensie, że stanowi ona źródło praw przysługujących uczelni. Nabycie praw przez uczelnię jako pracodawcę następuje bowiem ex lege w oparciu o przepisy regulujące zasady nabycia praw własności intelektualnej. Podjęcie decyzji o komercjalizacji lub bezskuteczny upływ terminu na jej podjęcie nie powoduje „,utraty” praw, a tylko aktywizuje obwiązek złożenia przez uczelnię pracownikowi oferty nabycia praw zgodnie z art. 86e ust. 2 p.s.w. ${ }^{22}$ Warto zaznaczyć, że decyzja taka nie ma charakteru decyzji administracyjnej, a co za tym idzie pracownikowi nie przysługuje od niej odwołanie do organów administracji.

Implementowane do p.s.w. rozwiązanie ma na celu ,zdyscyplinowanie” uczelni w zakresie podejmowania decyzji o komercjalizacji z założeniem, że jeśli uczelnia nie jest nią zainteresowana, kompetencje w tym zakresie - jako nabywca praw do wyników badań - może przejąć twórca. Należy jednak zauważyć, że stworzenie i realizowanie na uczelni efektywnych procedur w tym zakresie stanowi duże wyzwanie. Ustawowy okres trzech miesięcy może być w praktyce za krótki, aby w sposób efektywny i wiarygodny zweryfikować potencjał komercjalizacyjny i opcje komercjalizacji i na tej podstawie podjąć decyzję w sprawie komercjalizacji. Stąd rekomendowane jest stworzenie wewnętrznych procedur podejmowania decyzji, precyzujących przebieg procedury podejmowania decyzji, podmioty zaangażowane $\mathrm{w}$ ten proces oraz zakres informacji, które zobowiązany jest notyfikować pracownik (np. w postaci stosowanych postanowień regulaminowych albo formularza notyfikacji, stanowiącego załącznik do takiego regulaminu). W tym kontekście zasadne jest przyjęcie, że bieg terminu na podjęcie decyzji o komercjalizacji rozpoczyna się od momentu ,skutecznego zgłoszenia" przez pracownika informacji o stworzeniu wyników, w celu uniknięcia sytuacji w których dokonuje on co prawda notyfikacji, ale

publicznych (pracownikom, doktorantom, studentom) prawa własności intelektualnej do wyników ich twórczości, uczelni jako pracodawcy przyznając prawo pierwokupu lub prawo pierwszeństwa nabycia takich praw. $Z$ tego powodu proponowane zmiany określono mianem „uwłaszczenia pracowników uczelni”, które to sformułowanie jest nieadekwatne w stosunku do rozwiązań przyjętych w uchwalonej nowelizacji.

21 Przyjęte rozwiązanie przypomina stosowany w niektórych krajach (np. w norweskiej ustawie o wynalazkach pracowniczych z 1970 r.), reżim nabycia praw do własności pracowniczej (tzw. claiming the right regime), polegający na tym, że pracodawca nabywa prawa do wynalazku stworzonego w ramach wykonywania obowiązków pracowniczych, jeżeli w ciągu pewnego okresu czasu (zwykle od 3 do 6 miesięcy) od uzyskania od pracownika informacji o stworzeniu wynalazku rozpocznie wykonywanie praw do wynalazku. Pracownikowi należy się wynagrodzenie, chyba że wartość rynkowa wynalazku jest niewielka. szkole wyższej będą przysługiwać prawa do wyników badań”, (w:) Prawa do wyników badań..., op. cit, s. 1176. 
przekazane informacje są niekompletne i nie dają podstaw do podjęcia na ich podstawie stosownej decyzji przez uczelnię.

Formalnie, stosowanie wyżej przedstawionego ustawowego trybu jest obligatoryjnym elementem procesu zarządzania wynikami badań naukowych i prac rozwojowych stworzonych przez pracownika w ramach wykonywania obowiązków pracowniczych. Przepisy p.s.w. przewidują jednak jeszcze jedną możliwość, a mianowicie uregulowanie między uczelnią i pracownikiem kwestii nabycia praw i trybu komercjalizacji takich wyników na drodze umownej (art. 86i p.w.p.). Zakres zastosowania tego przepisu nie jest jednak jasny.

$\mathrm{Z}$ jednej strony, odwołanie do „odmiennego od ustawowego uregulowania na drodze umowy ,praw do wyników lub sposobu i trybu komercjalizacji tych wyników", powinno - jak się wydaje - stwarzać możliwość swobodnego regulowania przez strony wszystkich aspektów z komercjalizacją wyników badań, w tym kwestii terminów, obowiązków stron, podziału środków z komercjalizacji. Z drugiej strony, zgodnie z interpretacją przepisów art. 86 p.s.w. nie obejmuje on możliwości umownej modyfikacji ustawowych progów procentowych i zasad wypłaty wynagrodzenia. W zakresie, w jakim na drodze umownej zasady dotyczące wynagrodzenia pracownika mogłyby być zmodyfikowane na jego korzyść, interpretacja taka wydaje się nieuzasadniona.

\section{Ustawowe zasady podziału środków uzyskanych z komercjalizacji wyników badań naukowych i prac rozwojowych}

Nowym rozwiązaniem, wprowadzonym nowelizacją p.s.w. z 2014 r. jest uregulowanie minimalnego udziału procentowego pracownika (zespołu badawczego składającego się z pracowników) w środkach uzyskanych z komercjalizacji wyników badań lub prac rozwojowych dokonanej przez uczelnię oraz wskazanie ustawowego progu procentowego partycypowania uczelni w zyskach z komercjalizacji uzyskanych przez pracownika.

Zgodnie $\mathrm{z}$ art. 86f p.s.w., w przypadku dokonanej przez uczelnię publiczną komercjalizacji, pracownikowi przysługuje nie mniej niż 50\% wartości środków uzyskanych przez uczelnię z komercjalizacji bezpośredniej lub spółkę celową w następstwie komercjalizacji pośredniej, obniżonych o nie więcej niż 25\% kosztów bezpośrednio związanych z tą komercjalizacją, które zostały poniesione przez uczelnię lub spółkę celową. Jeśli środki zostaną uzyskane przez spółkę celową w następstwie komercjalizacji pośredniej, pracownikowi - twórcy ustawa gwarantuje nie mniej niż $50 \%$ ich wartości, ${ }^{23}$ obniżonych o nie więcej niż $25 \%$ kosztów bezpośrednio związanych z tą komercjalizacją, które zostały poniesione przez uczelnię lub spółkę 
celową. Zgodnie z definicją ustawową, „koszty związane bezpośrednio w komercjalizacją", obejmują koszty zewnętrzne, w szczególności koszty ochrony prawnej, ekspertyz, wyceny wartości przedmiotu komercjalizacji i opłat urzędowych, natomiast nie obejmują kosztów poniesionych przed podjęciem decyzji o komercjalizacji oraz wynagrodzenia wypłaconego pracownikowi z tytułu przeniesienia praw do wyników badań. ${ }^{24}$

Ciekawym rozwiązaniem przewidzianym w przepisach p.s.w., niespotykanym na gruncie ustaw ogólnych, jest zagwarantowanie uczelni publicznej jako zbywcy praw do wyników badań naukowych i prac rozwojowych ustawowego prawa do partycypowania $\mathrm{w}$ korzyściach $\mathrm{z}$ komercjalizacji dokonanej przez pracownika $\mathrm{w}$ wysokości $25 \%$ wartości takich środków, obniżonych o nie więcej niż $25 \%$ kosztów bezpośrednio związanych $\mathrm{z}$ tą komercjalizacją, poniesionych przez pracownika. Wskazane wyżej prawa pracownika i uczelni do partycypowania w korzyściach z komercjalizacji trwają przez okres 5 lat od dnia uzyskania pierwszych korzyści z komercjalizacji.

$\mathrm{Na}$ tle interpretacji i stosowania wskazanych ustawowych zasad dotyczących podziału środków z komercjalizacji nasuwają się następujące pytania i problemy.

Po pierwsze, rozstrzygnięcia wymaga kwestia relacji art. $86 \mathrm{f}$ oraz art. 22 ust. 1 p.w.p., regulującego kwestię wynagrodzenia twórcy $\mathrm{z}$ tytułu korzystania $\mathrm{z}$ wynalazku, wzoru użytkowego oraz wzoru przemysłowego. W tym zakresie należy przyjąć, że przepis przewidziany w p.s.w. jest przepisem szczególnym w stosunku do przepisów ogólnych (pr.aut. oraz p.w.p.), a co za tym idzie w zakresie kalkulacji wynagrodzenia należnego pracownikowi uczelni publicznej z tytułu komercjalizacji tych wytworów jako wyników badań naukowych i prac badawczych wyłącza stosowanie ogólnych zasad. ${ }^{25}$

Po drugie, pojawia się pytanie, czy przewidziane w p.s.w. przepisy dotyczące zasad podziału środków, ich procentowej wysokości, zasad kalkulacji oraz okresu trwania praw do partycypowania w korzyściach mogą być zmodyfikowane w oparciu o art. 86h p.s.w. przewidujący możliwość umownego regulowania kwestii nabycia i trybu komercjalizacji wyników badań i prac rozwojowych. $Z$ jednej strony, zgodnie z interpretacją MNiSW, nawet w przypadku odmiennego, umownego uregulowania trybu komercjalizacji, strony związane są ustawowymi zasadami podziału korzyści określonymi w art.86f p.s.w., gdyż jako przepis bezwzględnie obowiązujący nie może być zmieniony w drodze umowy. ${ }^{26} \mathrm{Z}$ drugiej strony, można argumen-

Zgodnie z art. 86g p.s.w., gdy komercjalizacja dotyczy wyniku badań naukowych lub prac rozwojowych stworzonych przez pracowników wchodzących w skład zespołu badawczego, ustawowe zasady określają wysokość łącznego wynagrodzenia oraz udziału w tych środkach, przysługujących uczelni publicznej od pracowników wchodzących w skład zespołu badawczego. wadzka, Zasady wynagradzania twórców-pracowników oraz podziału środków uzyskanych z komercjalizacji, (w:) J. Ożegalska-Trybalska, Regulaminy..., op. cit., s. 57. 
tować, że strony umowy korzystając z tej podstawy prawnej oraz zasady swobody zawierania umów powinny mieć pozostawioną możliwość decydowania, na jakich zasadach finansowych chcą komercjalizować prawa do wyników badań i prac rozwojowych, w tym dowolnie regulować m.in. kwestie podziału korzyści proporcjonalnie do ich obowiązków i obciążeń umownych związanych z uzyskaniem ochrony, prowadzeniem procesów komercjalizacji itp.

Warto zauważyć, że żaden przepis dyspozytywny przewidziany w pr.aut. czy p.w.p., umożliwiający stronom odmienne od ustawowego regulowanie kwestii nabycia i zarządzania prawami, nie wprowadza podobnych ograniczeń w zakresie wynagrodzenia czy zasad podziału środków z tytułu korzystania z praw własności intelektualnej. Przeciwnie, jak się wydaje ideą tych przepisów (w szczególności adekwatnego tu art. 22 p.w.p.) jest przyznanie prymatu swobodzie regulowania tego typu kwestii przez strony umowy, w celu uelastycznienia procesów komercjalizacji. ${ }^{27}$ Swoboda ta powinna dotyczyć także ustalenia okresu, w jakim przysługuje prawo do wynagrodzenia (art. 22 ust. 3 p.w.p.).

Przy założeniu, że wskazany w art. 86 f ust. 5 p.s.w. 5-letni okres stanowi maksymalny okres, w trakcie którego pracownik może skutecznie domagać się wypłaty należnej mu części środków z komercjalizacji oraz, że termin ten nie może być zmodyfikowany w umowie zawartej w trybie art. 86h p.s.w., może okazać się, że ustawowa regulacja nie zabezpiecza w sposób efektywny dochodów pracownika z komercjalizacji. ${ }^{28}$ Jak się słusznie zwraca uwagę, w praktyce okres ten będzie często za krótki z punktu widzenia uzyskania środków z komercjalizacji. Najwyższe dochody z komercjalizacji są generowane na długo po uzyskaniu pierwszych korzyści z komercjalizacji (np. zabezpieczonej przy podpisaniu umowy opłaty ryczałtowej przewidzianej obok opłat okresowych).

\section{Prawa i obowiązki pracowników, doktorantów i studentów związane z komercjalizacją}

Niezbędnym uzupełnieniem regulacji określających ustawowy tryb nabycia i komercjalizacji praw do wyników badań i prac rozwojowych jest wzmocnienie roli twórcy-pracownika poprzez uregulowanie praw i obowiązków związanych z ochroną i efektywną komercjalizacją, które odpowiadałyby potrzebom i specyfice tych procesów.

Do najważniejszych, ustawowych obowiązków nałożonych na pracownika należy zgłaszanie wyników badań naukowych i prac rozwojowych oraz know-how

27 Por: J. Czarnecki, Nowe zasady komercjalizacji badań naukowych, „Biuletyn Nowe technologie. Prace Badawcze, Wardyńscy i Wspólnicy”, luty 2015, dostępny pod adresem: http://www.wardynski.com.pl/biuletyn_nowych_ technologii/2015-02/B01_PL_Komercjalizacja.pdf (data dostępu: 22.05.2015 r.).

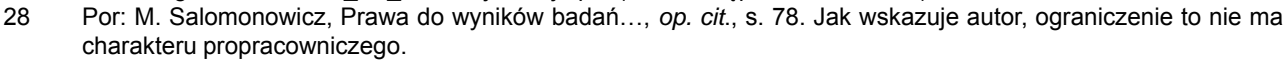


związanego z tymi wynikami, a także przekazywanie uczelni publicznej wszystkich posiadanych przez niego informacji, utworów wraz z własnością nośników, na których utwory te utrwalono i doświadczeń technicznych potrzebnych do komercjalizacji.

Zakres tego obowiązku jest niewątpliwie szeroki, ale uzasadnieniem takiego jego ujęcia jest potrzeba dostępu uczelni do objętych obowiązkiem dóbr, informacji, doświadczeń w celu zagwarantowania możliwości sprawnego prowadzenia procesów komercjalizacyjnych. Do pozostałych ustawowych obowiązków należą: obowiązek zachowania wyników badań w poufności, powstrzymania się od prowadzenia jakichkolwiek działań zmierzających do wdrażania wyników oraz współdziałania $\mathrm{w}$ procesie komercjalizacji, $\mathrm{w}$ tym $\mathrm{w}$ postępowaniach zmierzających do uzyskania praw wyłącznych. O ile dwa z pierwszych wymienionych obowiązków wydają się ze sobą logicznie powiązane, to wątpliwości budzić może połączenie zakazu podejmowania działań zmierzających do komercjalizacji z nakazem podejmowania niezbędnych aktywności w procesach komercjalizacyjnych. Choć jakby się mogło wydawać obowiązki te się logicznie wykluczają, faktycznie nie będzie między nimi sprzeczności tak daleko jak przyjmiemy, że w praktyce ich realizacja odbywać się może na innych etapach zarządzania wynikami i komercjalizacji wyników badań. Niewątpliwie, po notyfikacji badań, a przed podjęciem decyzji o komercjalizacji pracownik powinien powstrzymać się od podejmowanych na własną rękę działań komercjalizacyjnych, choćby z tego powodu, że nie jest uprawniony do wyników badań, a swymi działaniami mógłby zaszkodzić zabezpieczeniu ich ochrony przez uczelnię jako podmiot uprawniony. Natomiast na kolejnych etapach komercjalizacji (np. wdrażania wyników) powinien współdziałać z uczelnią w celu efektywnej komercjalizacji i to bez względu na to, do kogo ostatecznie należą prawa do wyników. W każdym przypadku, od wsparcia ze strony pracownika jako twórcy często zależeć będzie bowiem sukces komercjalizacji i dochody z tego tytułu, w których zagwarantowany udział ma tenże pracownik.

Pewne wątpliwości związane $\mathrm{z}$ realizacją wskazanych wyżej obowiązków pracownika uczelni publicznej mogą pojawić się w odniesieniu do tego, jak długo jest on nimi związany. $Z$ jednej strony wydaje się, że jako obowiązki pracownicze powinny wygasać z momentem ustania stosunku pracy. Do takiego wniosku, przynajmniej w stosunku do niektórych z obowiązków, prowadzi także wykładnia celowościowa. Przykładowo, po tym jak pracownik nie jest już związany z uczelnią stosunkiem pracy, nieuzasadnione wydaje się egzekwowanie obowiązku w postaci współdziałania np. w postępowaniach zmierzających do uzyskania praw wyłącznych. Nałożenie takiego ustawowego obowiązku mogłoby być uznane za dyskryminujące w stosunku do innych twórców wytworów pracowniczych, którzy nie są zobowiązani do „wspierania procesów komercjalizacyjnych” byłego pracodawcy.

Także obowiązek zachowania wyników badań w poufności wydaje się być ograniczony czasowo np. momentem publikacji zgłoszenia patentowego, którego 
elementem są takie wyniki. Nie ma racjonalnego powodu, żeby pracownik był zobowiązany do zachowania w poufności wyników, które i tak są publicznie dostępne w postaci opublikowanego opisu patentowego. Jeżeli uczelnia pozostaje podmiotem uprawnionym z tytułu praw do wyników badań i zabezpiecza ich ochronę, oczywisty wydaje się obowiązek pracownika, tak zresztą jak każdej osoby trzeciej, do powstrzymywania się od działań związanych z bezprawnym korzystaniem z takich wyników, np. w ramach samodzielnie prowadzonych przez pracownika aktywności komercjalizacyjnych.

Obok ustawowych obowiązków, przypomnieć należy o wskazanych już wcześniej uprawnieniach pracownika wynikających z przepisów p.s.w. Należą do nich: prawo nabycia od uczelni praw do wyników badań w przypadku podjęcia decyzji o niekomercjalizacji lub niepodjęcia decyzji przez uczelnię w ustawowym terminie, za kwotę nieprzekraczającą ustawowo określonego pułapu, prawo do wynagrodzenia z tytułu uzyskania środków z komercjalizacji w wysokości nie niższej niż określonej w przepisach p.w.p.

Choć znowelizowane przepisy p.s.w. dotyczą zasadniczo pracowników uczelni publicznych, niektóre z nich odnoszą się także do studentów i doktorantów. ${ }^{29}$ W świetle art. 86c ust. 2 pkt. 2 p.s.w. na tę kategorię twórców nałożony został jedynie obowiązek przekazywania uczelni publicznej informacji o wynikach badań naukowych lub prac rozwojowych oraz o know-how związanym z tymi wynikami, przy czym zasady i tryb realizacji tego obowiązku powinna indywidualnie określić uczelnia publiczna w swoim regulaminie.

Realizacja tego obowiązku nie ma jednak żadnego wpływu na prawa studentów i doktorantów do ich twórczości. W założeniu ustawodawcy ma on umożliwić uczelni monitorowanie takich wyników po to, aby w przypadku zainteresowania komercjalizacją mogła ona podjąć negocjacje ze studentem lub doktorantem zmierzające do nabycia praw do takich wyników na podstawie odrębnych umów. ${ }^{30}$

\section{Wnioski końcowe}

W związku z wprowadzeniem nowego modelu nabycia i komercjalizacji praw do wyników badań naukowych i prac rozwojowych, uczelnie publiczne stanęły przed trudnym zadaniem przystosowania swoich regulaminów oraz wewnętrznych procedur w celu realizacji ustawowych obowiązków w zakresie zarządzania własnością intelektualną. Krótki czas obowiązywania nowych przepisów nie pozwala na formu-

\footnotetext{
29 Por: M. Salomonowicz, Prawa do wyników badań..., op.cit., s. 1175. Autor co prawda wskazuje, że zakres podmiotowy nowych przepisów ogranicza się wyłącznie do pracowników uczelni publicznej, ale w kontekście zasad nabycia praw do wyników badań, co tłumaczyłoby tak określony krąg adresatów znowelizowanych przepisów p.s.w.

Tak: stanowisko MNiSW z dnia 27 listopada 2014 r. nr DIR.ZSA.555.67.2014 (niepub.).
} 
łowanie wniosków co do ich wpływu na zwiększenie działalności twórczej na uczelniach i efektywności prowadzonych przez nie procesów komercjalizacyjnych.

Próbując na tym etapie ocenić nowy model można zauważyć, że w założeniu jest on o tyle korzystny, iż z jednej strony obliguje pracowników do zgłaszania stworzonych przez siebie rozwiązań, $z$ drugiej strony dyscyplinuje uczelnie do zainteresowania się możliwością ich komercjalizacji w określonym terminie, pod rygorem „utraty” praw do takich rozwiązań . W praktyce, stosowanie nowych przepisów może być jednak trudne, zwłaszcza w zakresie terminowego podejmowania przez uczelnie decyzji o komercjalizacji, a także stosowania trybu ustawowego w sytuacjach, gdy wyniki badań naukowych i prac rozwojowych stanowią rezultat pracy zespołu badawczego, w którego skład wchodzą twórcy o różnym statusie z punktu widzenia stosowania przepisów p.s.w. (pracownicy, doktoranci, studenci, podmioty z zewnątrz), a prace prowadzące do ich uzyskania są finansowane z różnych źródeł.

W tym zakresie istotne jest, aby już na początku obowiązywania nowych przepisów, ich interpretacja dokonywana była w sposób odpowiadający założeniom przyświecającym zmianom p.s.w. Dotyczy to w szczególności właściwego interpretowania art. $86 \mathrm{~h}$ p.s.w., gwarantującego możliwość odbiegającego od wymogów ustawowych, swobodnego uregulowania w umowie między uczelnią i pracownikiem trybu i zasad komercjalizacji, odpowiadającego specyfice wyników, warunków, w jakich zostały uzyskane oraz potrzebom stron. 


\section{MODEL ACQUISITION AND COMMERCIALIZATION OF THE RESULTS OF RESEARCH AND DEVELOPMENT IN THE LIGHT OF THE LAW ON HIGHER EDUCATION}

The article is focused on the most important rules establishing a statutory model for commercialisation of R\&D results, in the light of the 2014 amendments to the Law on Higher Education. It consists of an analysis focused on, among others: statutory tools supporting IP management at universities, statutory rules of obtaining rights to $\mathrm{R} \& \mathrm{D}$ results and rules for sharing benefits from commercialisation. The article also mentions possible problems with interpretation of particular statutory provisions as well as provides answers to some questions, which may arise in practice.

Słowa kluczowe: zarządzanie własnością intelektualną na uczelniach, uczelniane regulaminy zarządzania własnością intelektualną, prawa do wyników badań naukowych i prac rozwojowych, komercjalizacja badań naukowych i prac rozwojowych, nowelizacja ustawy o szkolnictwie wyższym

Keywords: Management of IP at universities, IP regulations at universities, IP rights to R\&D results, R\&D commercialization, amendment of the Law on Higher Education 